\title{
STUDY OF ACUTE TOXICITY OF THE DRUG «KOLIDEV 8M» WITH A SINGLE INTRAGASTRIC INJECTION IN LABORATORY ANIMALS
}

\author{
Roman Sachuk, Yaroslav Stravsky, Bogdan Gutyj, Tetiana Velesyk, Orest Katsaraba, \\ Sergii Zhyhalyuk
}

«Kolidev 8M» (powder for oral use) is a veterinary drug used to treat ornamental birds (pheasants, peacocks) in diseases of the digestive tract caused by microorganisms sensitive to colistin.

In the study of the drug «Kolidev 8M» for oral administration, along with the confirmation of therapeutic properties, it is necessary to determine the $L D_{50}$ obtained in the process of studying acute toxicity.

The aim of research. The aim of research was to determine the acute toxicity of the veterinary drug "Kolidev 8M» (powder for oral administration) under the conditions of intragastric administration to white mice.

Materials and methods of research. To achieve this aim, an experiment was conducted on 114 males of nonlinear white mice kept under optimal conditions in the vivarium of DEVIE LLC (Rivne, Ukraine). In the first series of experiments on the principle of analogues was formed control and three experimental groups of 6 animals each $(n=6)$. The drug in the form of a solution was administered once orally using a esophageal gastric tube in doses of 500,0; 2000,0 and $4000,0 \mathrm{mg} / \mathrm{kg}$ body weight by absolute weight of the drug. The animals of the control group were injected with distilled water.

After taking into account the results of the first experiment in the next experiment, 6 experimental groups were formedmice, which were administered the drug «Kolidev 8M» in the form of a solution in doses (by absolute weight of the drug) - 500,0; 1000,0; 1500,0; 2000.0; 2500,0; 3000,0; 3500 and 4000,0 mg/kg body weight, as well as the control group - animals that were injected with distilled water with a volume of $0.5 \mathrm{~cm}^{3}$ according to similar regulations (Zapadniuk, 1983; Kotsiumbas, 2005; Karkyshchenko \& Hrachev, 2010). There were 6 animals in each group (n=6). After their death, a pathological autopsy was performed (Zharov A. et al., 2003).

The average lethal dose of $L D_{50}$ was calculated by the method of probit analysis by Prozorovsky V.B.

Research results. According to the results of research, it was found that the LD50 of the drug "Kolidev 8M» (powder for oral administration) under the conditions of its single intragastric administration to male mice is 2024,72 \pm $\pm 232,45 \mathrm{mg} / \mathrm{kg}, \mathrm{LD} D_{10}-392,87 \mathrm{mg} / \mathrm{kg}, L D_{16}-751,56 \mathrm{mg} / \mathrm{kg}, L D_{84}-3297,88 \mathrm{mg} / \mathrm{kg}, \mathrm{LD} D_{90}-3656,57 \mathrm{mg} / \mathrm{kg}, \mathrm{LD} 100-$ $3934,47 \mathrm{mg} / \mathrm{kg}$ body weight, respectively.

According to the results of an acute toxicological experiment with intragastric administration of the drug "Kolidev 8M》 to white male mice, $L D_{50}$ was $2024,72 \pm 232,45 \mathrm{mg} / \mathrm{kg}$ body weight. This allows, according to toxicity, to refer this drug to class IV - low-toxic substances ( $L D_{50} 501,0-5000,0 \mathrm{mg} / \mathrm{kg}$ body weight), and the degree of danger to class III - moderately safe substances ( $L D_{50} 151,0-5000,0 \mathrm{mg} / \mathrm{kg}$ body weight).

Conclusions and prospects for further research. The drug «Kolidev 8M» in terms of toxicity belongs to class IV - lowtoxic substances, and the degree of danger to class III - moderately safe substances.

Further studies will be the next stage of pre-registration trials aimed at studying the subacute toxicity of the drug «Kolidev 8M»

Keywords: colistin, mice, group, experiment, dose, lethality, autopsy, toxicity, degree of danger, «Kolidev 8M»

How to cite:

Sachuk, R., Stravsky, Ya., Gutyj, B., Velesyk, T., Katsaraba, O., Zhyhalyuk, S. (2021). Study of acute toxicity of the drug «kolidev 8m» with a single intragastric injection in laboratory animals. ScienceRise: Biological Science, 2 (27), 44-48. doi: http://doi.org/10.15587/2519-8025.2021.235952

(C) The Author(s) 2021

This is an open access article under the Creative Commons CC BY license

\section{Introduction}

For the treatment of diseases of the gastrointestinal tract of ornamental birds (pheasant, peacock) caused by microorganisms sensitive to colistin, LLC «DEVIE» developed a new antibacterial drug «Kolidev 8M» (powder for oral use). The drug contains a natural antibiotic of the polypeptide group Colistin (polymyxin E), produced by the aerobic spore-forming bacillus Bacillus polymyxa var Colistinus. $1 \mathrm{~g}$ of the drug contains the active substance colistin sulfate $-8,000,000$ IU and the excipient lactose monohydrate. Prerequisites for pre-clinical and clinical trials, primarily toxicological studies in laborato- ry animals, are a prerequisite for the use of new drugs [1]. This condition is reflected in the Helsinki Declaration of the World Medical Association «Ethical principles of medical research with human participation as an object of study» and in the Law on Veterinary Medicine of Ukraine. The results of research, including the toxic effects of substances on the body, can be significantly influenced by concomitant factors, such as the condition and content of animals, their sex and age, and others [2]. Therefore, the first stage of the study should be to obtain information on the action of the test substance in a short-term experiment and determine the prospects for further testing. 
One of the important toxicological characteristics of drugs is harmlessness, which is characterized by a moderately toxic (medium lethal) dose of the drug $\mathrm{LD}_{50}$. In the study of a generic drug, along with the confirmation of therapeutic properties, it is necessary to determine the $\mathrm{LD}_{50}$ obtained in the process of studying acute toxicity [3]. This allows to determine the class of toxicity of the drug, the breadth of its therapeutic effect and the ratio of toxicity / harmlessness under conditions of use of the drug in doses tens and hundreds of times higher than therapeutic [4].

The aim of research was to study the acute toxicity of the drug «Kolidev $8 \mathrm{M} »$ in white rats and mice by intragastric administration.

\section{Materials and methods}

The drug «Kolidev 8M» was used during the experiment ( $1 \mathrm{~g}$ of the drug contains the active substance: colistin sulfate $-8,000,000$ IU), series №012, release form $500 \mathrm{~g}$, manufactured by Ltd «DEVIE» (Lityn, Ukraine). The experiment was conducted during AprilMay 2021 on 114 male nonlinear white mice 4 months of age and weighing (20-22) g, kept under optimal vivarium conditions «DEVIE» Ltd (Rivne, Ukraine) [5-7]: the room temperature was $18 \pm 2){ }^{\circ} \mathrm{C}$, relative humidity (6070) $\%$, lighting cycle day-night, during the experiment, was (10-14) h, and was provided 10-fold change in air volume in the vivarium room for an hour.

For feeding mice used complete feed for rodents. The animals had free access to water and food.

Mice were manipulated in accordance with existing regulations in line with ARRIVE guidelines and in accordance with the UK Animal Act (scientific procedures) 1986 and relevant guidelines or EU Directive 2010/63 / EU on the protection of animals used for scientific purposes.

Before the start of the study, each animal was weighed, and from the drug was prepared a solution in distilled water. Doses of «Kolidev 8M» (powder for oral administration) administered were calculated individually according to the weight of each mouse, with the volume of solution of the drug administered intragastrically at a time not exceeding $1.0 \mathrm{~cm}^{3}$. Determination of the dose range for the main experiment was performed in a previous experiment.

To this end, in a previous experiment on the principle of analogues was formed control and three experimental groups of 6 animals each $(n=6)$. The drug «Kolidev $8 \mathrm{M} »$ (powder for oral administration) in the form of a solution was administered in doses of 500,0; 2000,0 and 4000,0 mg/ $\mathrm{kg}$ body weight in absolute weight of the drug once orally using a esophageal gastric tube. The animals of the control group were injected with distilled water.

After taking into account the results of the previous experiment in the main experiment, 6 experimental groups were formed, whose mice were administered the drug «Kolidev 8M» (powder for oral use) in the form of a solution in doses (absolute weight of the drug) - 500,0; 1000,$0 ; 1500,0 ; 2000,0 ; 2500,0 ; 3000,0 ; 3500,0$ and $4000,0 \mathrm{mg} / \mathrm{kg}$ body weight, as well as a control group, the animals of which were injected with distilled water with a volume of $0,5 \mathrm{~cm}^{3}$ according to similar regulations. There were 6 animals in each group $(n=6)$.

The clinical condition of the experimental animals was observed for 14 days, noting the appearance and development of clinical signs of poisoning, the time of death or recovery to physiological norm. During the clinical examination, mice paid attention to behavior, reaction to external stimuli, appetite, skin condition, color of mucous membranes, frequency of respiration and defecation, changes in color and consistency of feces, etc. [5, 6].

After the death of the animals performed a pathological autopsy. To establish pathological changes, a macroscopic method of research was used [8]. Pathological autopsy was performed according to the following scheme:

- at the first stage, an external inspection was performed, noting the condition of the coat and mucous membranes;

- at the second - performed autopsy and examination of body cavities and internal organs, such as pharynx, trachea, larynx, heart, lungs, liver, spleen, kidneys, stomach, intestines, noting changes in color, consistency, pattern and shape of organs.

According to the results of death, $\mathrm{LD}_{10}, \mathrm{LD}_{16}$, $\mathrm{LD}_{50}, \mathrm{LD}_{84}, \mathrm{LD}_{90}, \mathrm{LD}_{100}$ and $\mathrm{LD}_{50}$ error were calculated by the method of probit analysis in the modification of V.B Prozorovskyi (GOST 12.1.007-76. SSBT).

The obtained results were processed by methods of variation statistics using the software package StatPlus 5.9.8.5. Data were presented as mean values with a standard deviation of $95 \%$ confidence level.

\section{Results}

At the first stage of the research, mice were administered the drug «Kolidev $8 \mathrm{M} »$ (powder for oral administration) in doses of 500,0; 2000,0 and 4000,0 mg/kg body weight. Clinical observations have shown that intragastric administration of the drug to mice of experimental group I $(500,0 \mathrm{mg} / \mathrm{kg}$ body weight) caused a slight inhibition, which disappeared within 2-3 hours after administration. On the first day after administration, the mice were mobile, responded well to external stimuli, and actively consumed food and water. Mouse deaths in this group were not observed during the 14-day followup period (table 1).

In mice of experimental group II $(2000,0 \mathrm{mg} / \mathrm{kg}$ body weight) in (20-30) min after administration of the drug recorded depression, which increased during the first day after administration, but the animals consumed food and water, sat mostly in one place, the reaction on external stimuli was reduced, when trying to move in 2 mice observed impaired coordination. On the 2nd day, two mice from the group had a more pronounced clinic of poisoning: mice were depressed, moved sluggishly, refused food, the animals showed thirst, fur was bulging, disheveled, during attempts to move recorded shaking, tremor of the pelvic limbs, then these animals were observed coma, convulsions and death (Table 1).

The clinical condition in 4 mice was gradually restored and did not differ from the control on the 7 th day of the experiment. 
Table 1

Dynamics of death of mice in a previous experiment to determine the acute toxicity of the drug «Kolidev $8 \mathrm{M} »$ (powder for oral administration) $(\mathrm{n}=24)$

\begin{tabular}{|c|c|c|c|c|}
\hline \multirow{3}{*}{$\begin{array}{l}\text { Terms of death } \\
\text { mice, through }\end{array}$} & \multicolumn{4}{|c|}{ Mouse groups and doses, $\mathrm{mg} / \mathrm{kg}$ body weight } \\
\hline & \multirow{2}{*}{ Control } & \multicolumn{3}{|c|}{ Experiment } \\
\hline & & $\mathrm{I}(500,0)$ & II $(2000,0)$ & III $(4000,0)$ \\
\hline $1-24$ hours & - & - & - & 4 \\
\hline 2 date & - & - & 2 & 2 \\
\hline 3 date & - & - & - & - \\
\hline 4-14 date & - & - & - & - \\
\hline All died & - & - & 2 & 6 \\
\hline
\end{tabular}

In mice of experimental group III, which were administered the drug at a dose of $4000.0 \mathrm{mg} / \mathrm{kg}$ body weight, a more pronounced clinical picture of poisoning was observed: after (15-20) minutes after drug administration, severe depression was recorded, which increased during the first day after administration. Mice sat mostly in one place, the reaction to external stimuli was reduced, when trying to move in all mice observed impaired coordination. In 4 mice, the depression increased, then observed coma, convulsions and death. At a similar clinic, 2 mice died on the 2 nd day after administration (Table 1).
At the next stage of the research mice were administered the drug «Kolidev $8 \mathrm{M} »$ (powder for oral administration) in doses of 500,$0 ; 1500,0 ; 2000,0 ; 2500,0$; 3000,$0 ; 3500,0$ and $4000,0 \mathrm{mg} / \mathrm{kg}$ body weight. Clinical observations showed that intragastric administration of the drug to mice of experimental group I $(500,0 \mathrm{mg} / \mathrm{kg}$ body weight) did not cause symptoms of acute poisoning, mice were mobile, responded well to external stimuli, actively consumed food and water. Mouse deaths in this group were not observed during the 14-day follow-up period (Table 2).

Table 2

Dynamics of death of mice in the main experiment to determine the acute toxicity of the drug «Kolidev 8M» (powder for oral administration) $(n=90)$

\begin{tabular}{|c|c|c|c|c|c|c|}
\hline \multirow{2}{*}{\multicolumn{2}{|c|}{$\begin{array}{c}\text { Mouse groups and doses, } \\
\mathrm{mg} / \mathrm{kg} \text { body weight }\end{array}$}} & \multicolumn{5}{|c|}{ Terms of death of mice, through } \\
\hline & & $1-24$ hours & 2 date & 3 date & 4-14 day & All died \\
\hline \multicolumn{2}{|c|}{ Control } & - & - & - & - & - \\
\hline \multirow{8}{*}{ 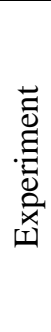 } & $\mathrm{I}(500,0)$ & - & - & - & - & - \\
\hline & II $(1000,0)$ & - & 2 & - & - & 2 \\
\hline & III $(1500,0)$ & - & 4 & - & - & 4 \\
\hline & IV $(2000,0)$ & 2 & 4 & - & - & 6 \\
\hline & $\mathrm{V}(2500,0)$ & 4 & 2 & - & - & 6 \\
\hline & VI $(3000,0)$ & 4 & 4 & - & - & 8 \\
\hline & VII $(3500,0)$ & 6 & 2 & - & - & 8 \\
\hline & VIII $(4000,0)$ & 8 & 2 & - & - & 10 \\
\hline
\end{tabular}

A similar but more pronounced clinical picture of poisoning was observed in mice of the II-III experimental groups (1000.0 and $1500.0 \mathrm{mg} / \mathrm{kg}$ body weight), but on the 2nd day there were deaths of two and 4 mice, respectively. The clinical condition of the surviving mice was restored on the 7th day of the experiment (Table 2). In the IV and V experimental groups 6 rats died, in VI and VII - 8, and in VIII experimental group within 2 days after administration all animals died (Table 2). The main symptoms of poisoning were severe depression, which increased during the first day after administration, the animals sat mainly in one place, decreased response to external stimuli, incoordination, coma, convulsions and death. The clinical condition of the surviving mice was restored for 7-9 days of the experiment.

After the death of the mice, a pathological autopsy was performed. An external examination of the carcasses of the experimental animals revealed that the fur had been disheveled; observed leakage from the oral and nasal cavities, the genital area was contaminated; noted cyanosis of the visible mucous membranes.
At autopsy in mice:

- cyanosis of the mucous membranes of the oral cavity, trachea, pharynx and esophagus was registered;

- stomach with food and drug residues, in some animals swollen, hyperemic mucosa;

- the heart is enlarged, the atria are full of blood;

- blood is not coagulated;

- the liver is enlarged, dark red in color, elastic consistency;

- in the lungs of some animals found fluid;

- spleen and pancreas - without changes; kidneys light brown, enlarged;

- catarrhal-hemorrhagic inflammation of the mucous membrane was found in the small and large intestine.

The next step in studying the toxicological characteristics of the drug «Kolidev $8 \mathrm{M} »$ (powder for oral administration) was to determine the average lethal dose and its standard error $\left(\mathrm{LD}_{50}, \mathrm{LD}_{10}, \mathrm{LD}_{16}, \mathrm{LD}_{84}, \mathrm{LD}_{90}, \mathrm{LD}_{100}\right)$.

The average lethal dose of $\mathrm{LD}_{50}$ was calculated by the method of probit analysis by V. Prozorovskyi. 
Toxicometric parameters of the drug were calculated by the method of least squares for probit analysis of mortality curves.

The percentage of lethality, probits (Y), weight coefficients of probits $(\mathrm{Z})$ are established.

To plot the abscissa, the values of the drug doses $(\mathrm{mg} / \mathrm{kg})$ were plotted, and the value of the effect $(\%)$ was plotted on the ordinate axis.

A graphical representation of the dose-effect curve for mice is shown in Fig. 1.

The results of calculating the average lethal dose of the drug for mice under intragastric administration are shown in Table 3.

According to the results of research, it was found that the LD50 of the drug «Kolidev 8M» (powder for oral administration) under the conditions of its single intragastric administration to male mice is $2024.72 \pm 232.45 \mathrm{mg} / \mathrm{kg}$, $\mathrm{LD}_{10}-392.87 \mathrm{mg} / \mathrm{kg}, \mathrm{LD}_{16}-751.56 \mathrm{mg} / \mathrm{kg}, \mathrm{LD}_{84}-$ $3297.88 \mathrm{mg} / \mathrm{kg}, \quad \mathrm{LD}_{90}-3656.57 \mathrm{mg} / \mathrm{kg}, \mathrm{LD}_{100} \quad-$ $3934.47 \mathrm{mg} / \mathrm{kg}$ body weight, respectively.

Therefore, the drug «Kolidev 8M» (powder for oral administration) in terms of toxicity can be classified as class IV - low-toxic substances $\left(\mathrm{LD}_{50}\right.$ 501,0-
$5000,0 \mathrm{mg} / \mathrm{kg}$ body weight), and the degree of danger to class III - moderately safe substances $\left(\mathrm{LD}_{50}-151,0\right.$ $5000,0 \mathrm{mg} / \mathrm{kg}$ body weight) [6].

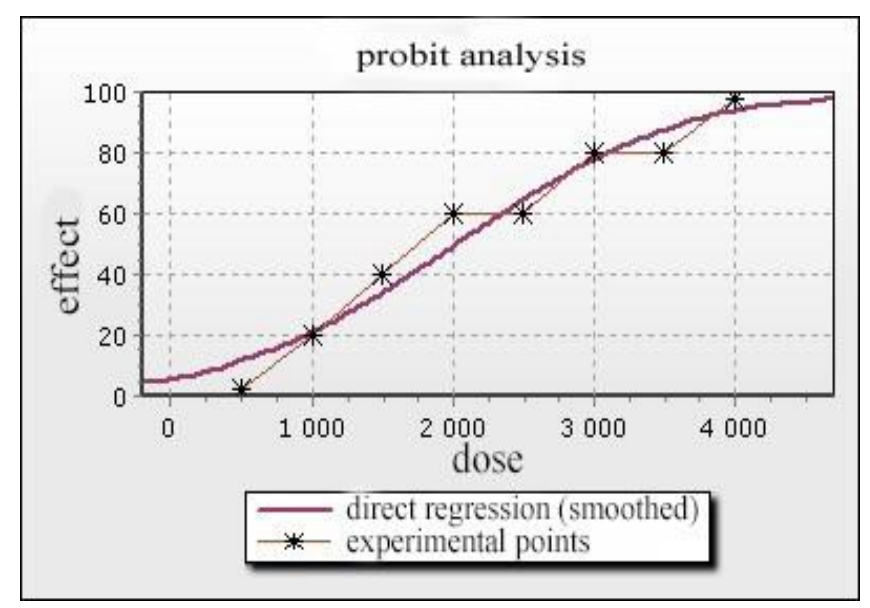

Fig. 1. Mortality curve of male mice under conditions of single intragastric administration of the drug «Kolidev $8 \mathrm{M} »$ (powder for oral administration)

Table 3

The results of the calculation of lethal doses of the drug «Kolidev $8 \mathrm{M} »$ (powder for oral administration) under the conditions of a single intragastric injection in male mice

\begin{tabular}{|c|c|c|c|c|}
\hline Stimulus (dose) & Interest (\%) & $\mathrm{N}$ & Probit (Y) & Weighting factor (Z) \\
\hline 500 & 0.025 & 10 & 3.0396 & 1.0792 \\
\hline 1000 & 0.200 & 10 & 4.1585 & 3.8171 \\
\hline 1500 & 0.400 & 10 & 4.7471 & 4.7471 \\
\hline 2000 & 0.600 & 10 & 5.2529 & 4.7471 \\
\hline 2500 & 0.600 & 10 & 5.2529 & 4.7471 \\
\hline 3000 & 0.800 & 10 & 5.8415 & 3.8171 \\
\hline 3500 & 0.800 & 10 & 5.8415 & 3.8171 \\
\hline 4000 & 0.975 & 10 & 6.9604 & 1.0000 \\
\hline \multicolumn{5}{|c|}{ Regression statistics } \\
\hline $\mathrm{LD}_{50}$ & 2024.72 & \multicolumn{2}{|c|}{$\mathrm{LD}_{50}$ Standard error } & 232.45 \\
\hline $\mathrm{LD}_{10}$ & 392.87 & $\mathrm{LD}_{16}$ & 751.56 & \\
\hline $\mathrm{LD}_{84}$ & 3297.88 & $\mathrm{LD}_{90}$ & 3656.57 & \\
\hline $\mathrm{LD}_{100}$ & 3934.47 & & & \\
\hline
\end{tabular}

\section{Discussion of research results}

The authors for the first time conducted preclinical studies of a new drug «Kolidev 8M» (powder for oral use) - a veterinary drug used to treat ornamental birds (pheasant, peacock) in diseases of the digestive tract caused by microorganisms sensitive to colistin. The relative safety and harmlessness of the drug «Kolidev 8M» for mice has been proven. It is confirmed that the drug belongs to the IV class - low-toxic substances, and the degree of danger - to the III class - moderately safe substances. The results of the research are consistent with the data of V.I. Parshin, V.E. Abramov (2010) [10]. At the stage of preclinical studies, the authors found that the drug based on enrofloxacin and colistin when administered intramuscularly in doses of 0,5 and $1,0 \mathrm{ml}$ per $10 \mathrm{~kg}$ of animal weight and multiple injections in a dose of $0,5 \mathrm{ml}$, does not adversely affect general condition of rabbits does not change the morphological and biochemical parameters of their blood. Preclinical studies of colistin by foreign researchers $[11,12]$ have established its safety and harmlessness. The $\mathrm{LD}_{50}$ of the colistin-based drug when administered intragastrically to laboratory animals (white rats and mice) is greater than $25,000 \mathrm{mg} / \mathrm{kg}$.

Research limitations. In order to obtain a permit for clinical trials of the drug «Kolidev $8 \mathrm{M} »$, with the subsequent introduction of development in industrial production and veterinary practice, it is necessary to complete the stage of drug development, which includes a set of toxicological studies, namely - determination of subacute and chronic toxicity.

Prospects for further research. Therefore, further studies will be the next stage of pre-registration tests aimed at studying the subacute toxicity of the powder for oral administration «Kolidev $8 \mathrm{M} »$.

\section{Conclusions}

According to the results of an acute toxicological experiment with intragastric administration of the drug «Kolidev 8M» (powder for oral administration) to white male mice $\mathrm{LD}_{50}$ was $2024,72 \pm 232,45 \mathrm{mg} / \mathrm{kg}$ body weight, 
which allows it to be classified as toxic class IV - low toxicity $\left(\mathrm{LD}_{50} 501,0-5000, \mathrm{mg} / \mathrm{kg}\right.$ body weight), and according to the degree of danger to class III - moderately safe substances $\left(\mathrm{LD}_{50}\right.$ 151,0-5000,0 mg/kg body weight).

\section{Conflict of interest}

The authors declare that they have no conflicts of interest.

\section{Funding}

The study was performed without financial support.

\section{Acknowledgment.}

The authors of the article express their gratitude to the General Director of DEVIE LLC Tverdom Y.M, who provided the drug «Kolidev $8 \mathrm{M} »$ for scientific research.

\section{References}

1. Gutyj, B., Grymak, Y., Hunchak, V., Mysak, A., Nazaruk, N., Brezvyn, O. et. al. (2018). Preclinical searches of the preparation Thireomagnile. Ukrainian Journal of Ecology, 8 (1), 688-695. doi: http://doi.org/10.15421/2018_267

2. Gutyj, B., Khariv, I., Binkevych, V., Binkevych, O., Levkivska, N., Levkivskyj, D., Vavrysevich, Y. (2017). Research on acute and chronic toxity of the experimental drug Amprolinsyl. Regulatory Mechanisms in Biosystems, 8 (1), 41-45. doi: http://doi.org/10.15421/021708

3. Gutyj, B., Paska, M., Levkivska, N., Pelenyo, R., Nazaruk, N., Guta, Z. (2016). Study of acute and chronic toxicity of 'injectable mevesel' investigational drug. Biological Bulletin of Bogdan Chmelnitskiy Melitopol State Pedagogical University, 6 (2), 174-180. doi: http://doi.org/10.15421/201649

4. Sachuk, R. M. (2019). Determination of toxicity indicators and assessment of the sensibilizing action of the preparation for the external use "Ointment for wounds." Journal for Veterinary Medicine, Biotechnology and Biosafety, 5 (3), 22-26. doi: http://doi.org/10.36016/jvmbbs-2019-5-3-5

5. Zapadniuk, Y. P., Zapadniuk, V. Y., Zakharyia, E. A., Zapadniuk, B. V. (1983). Laboratornыe zhyvotnыe. Razvedenye, soderzhanye, yspolzovanye v эksperymente. Kyiv: Vyshcha shkola, 383.

6. Kotsiumbas, I. Ya., Malyk, O. H., Patereha, I. P. et. al.; Kotsiumbas, I. Ya. (Ed.) (2006). Doklinichni doslidzhennia veterynarnykh likarskykh zasobiv. Lviv: Triada plius, 360.

7. Karkischenko, N. N., Grachev, S. V. (2010). Rukovodstvo po laboratornym zhivotnym i alternativnym modelyam v biomeditsinskikh tekhnologiyakh. Moscow: Profil, 358.

8. Zharov, A. V., Ivanov, I. V., Strelnikov, A. P. (2003). Vskrytie i patomorfologicheskaya diagnostika bolezney zhivotnykh. Kyiv: Kolos, 400.

9. Prozorovskiy, V. B. (2007). Statisticheskaya obrabotka rezultatov farmakologicheskikh issledovaniy. Psikhofarmakologiya i biologicheskaya narkologiya, 7 (3-4), 2090-2120.

10. Parshina, V. I., Abramov, V. E. (2010). Farmakodinamika i vliyanie na kachestvo produktov uboya inektsionnoy lekarstvennoy formy enrofloksatsina s kolistinom. Veterinarnaya patologiya, 4, 72-75.

11. Nation, R. L., Li, J. (2009). Colistin in the 21st century. Current Opinion in Infectious Diseases, 22 (6), 535-543. doi: http://doi.org/10.1097/qco.0b013e328332e672

12. Reed, M. D., Stern, R. C., O'Riordan, M. A., Blumer, J. L. (2001). The Pharmacokinetics of Colistin in Patients with Cystic Fibrosis. The Journal of Clinical Pharmacology, 41 (6), 645-654. doi: http://doi.org/10.1177/00912700122010537

Received date 20.04.2021

Accepted date 27.05.2021

Published date 30.06.2021

Roman Sachuk*, Doctor of Veterinary Sciences, Senior Researcher, Department of Ecology, Geography and Tourism, Rivne State Humanitarian University, S. Bandery str., 12, Rivne, Ukraine, 33028

Stravskyy Yaroslav, Doctor of Veterinary Sciences, Senior Researcher, Department of Medical Biology, I. Horbachevsky Ternopil National Medical University, Voli sq., 1, Ternopil, Ukraine, 46001

Bogdan Gutyj, Doctor of Veterinary Sciences, Professor Department of Pharmacology and Toxicology, Stepan Gzhytskyi National University of Veterinary Medicine and Biotechnologies Lviv, Pekarska str., 50, Lviv, Ukraine, 79010

Tetiana Velesyk, PhD, Department of Ecology, Geography and Tourism, Rivne State Humanitarian University S. Bandery str., 12, Rivne, Ukraine, 33028

Orest Katsaraba, PhD, Associate Professor, Department of Obstetrics, Gynecology and Biotechnology of Animal Reproduction named after G. V. Zvereva, Stepan Gzhytskyi National University of Veterinary Medicine and Biotechnologies Lviv, Pekarska str., 50, Lviv, Ukraine, 79010

Sergii Zhyhaliuk, Biologist, Rivne Gymnasium «Harmoniya», Henerala Bezruchko ave., 26, Rivne, Ukraine, 33022

*Corresponding author: Sachuk Roman,e-mail: sachuk.08@ukr.net 